\title{
Serious leisure and the DIY approach to heritage: Considering the costs of career volunteering in community archives and museums
}

\author{
This article takes a serious leisure perspective to examine the costs associated \\ with career volunteering in DIY heritage institutions focused on the collection, \\ preservation and curation of popular music's past. While the rewards of serious \\ leisure have been analysed extensively in the literature, costs are addressed less \\ frequently. Moreover, Stebbins' framing of costs has been critiqued as \\ ambiguous and underdeveloped. In this article, we draw on Stebbins' tripartite \\ model of tensions, dislikes and disappointments to analyse costs that emerged \\ from ethnographic interviews undertaken with volunteers in 13 DIY popular \\ music heritage institutions. Types of costs included tensions that were \\ interpersonal, relational, financial, temporal (work, family, leisure), and related to \\ well-being (emotional, physical); dislikes centred on shortages of dependable \\ volunteers, volunteers who demonstrate a 'lack of care', and ineffective \\ leadership; and disappointments focused on being let down by others, \\ unsuccessful funding applications, and organisational change. Although rewards \\ outweigh costs, we find that recognising the costs involved for career volunteers \\ in DIY heritage institutions is crucial for contextualising rewards and \\ perseverance, as well as for understanding how different types of costs overlap \\ and exacerbate one another.
}

Keywords: career volunteering, popular music heritage, DIY institutions, serious leisure perspective, costs

\section{Introduction}

Over recent years, there has been a proliferation of heritage institutions - archives, museums and halls of fame - dedicated to collecting, preserving and exhibiting popular music's material past (see, e.g., Baker, 2017; Leonard, 2018). Some of these institutions constitute 'officially authorised' (Roberts \& Cohen, 2014), mainstream heritage institutions, which are often sanctioned and funded by government bodies and run primarily by paid staff with the support of volunteers. Others, however, are 'selfauthorised' (Roberts \& Cohen, 2014) initiatives - community-based, 'do-it-yourself' 
(DIY) institutions that are founded by enthusiasts, run predominantly by volunteers, and have limited spatial, financial and human resources (Baker, 2017). As organisations that are managed and sustained almost completely by volunteers, DIY heritage institutions are sites in which expressions of 'serious leisure' and 'career volunteering' flourish (Elkington \& Stebbins, 2014; Stebbins, 1996, 2014). In other words, the survival and efficacy of these institutions depends on the ongoing commitment, expertise and hard work of volunteers.

From a serious leisure perspective, career volunteers are motivated by the benefits and 'rewards' they accrue, but they also inevitably experience some drawbacks or 'costs' (Stebbins, 2005). While the rewards of serious leisure have been analysed extensively in the literature, less attention has been paid to the costs (Lamont, Kennelly, \& Moyle, 2015). There is also limited research on the experiences of volunteers in institutions preserving popular music's past, and the work that has been done has a tendency to focus on rewards, to the extent that it might be accused of being boosterist in approach (e.g. Baker, 2017; Cantillon \& Baker, 2018). This article provides some balance to the more celebratory scholarship by investigating how the costs of career volunteering manifest in DIY popular music heritage institutions. Focusing on interviews undertaken with volunteers in 13 DIY popular music heritage institutions from around the world, we discuss the notable tensions, dislikes and disappointments present in the data. Although costs are outweighed by rewards in these places, we find that it is nonetheless important to acknowledge the complex dynamics between costs, rewards and perseverance in order to better understand the career volunteer experience, and how this impacts on individual and institutional well-being.

\section{Literature review: Rewards and costs of serious leisure volunteering}

Volunteering is an unpaid, 'non-obligatory' activity undertaken for 'the benefit of 
others' or to contribute to society or an organisation (Dekker \& Halman, 2003, p. 1). Volunteer work can also be described as a kind of leisure activity that benefits the participant. In particular, volunteering can often manifest as 'serious leisure' - the 'systematic pursuit of an amateur, hobbyist or volunteer activity' that entails deploying and learning 'special skills, knowledge and experience' (Elkington \& Stebbins, 2014, p. 4). This is distinct from casual leisure, which Stebbins suggests is more 'short-lived', 'immediately intrinsically rewarding' and requires 'little or no special training to enjoy it' (Stebbins, 2015, p. 13). Similar to paid workers, serious leisure volunteers express a degree of seriousness - 'earnestness, sincerity, importance, and carefulness' - in their activities, and are committed to completing designated tasks at particular places and times (Stebbins, 2014, p. 5; Stebbins, 1996). However, unlike paid workers, serious leisure volunteers receive no financial remuneration, and are rather motivated by the 'durable benefits' and rewards their activity yields (Stebbins, 1996, 2015). Veal (2017, p. 214) stresses that it is important to avoid a 'serious/casual dichotomy', and that it is instead more useful to consider leisure activities on a continuum of seriousness. In this article, we are primarily concerned with volunteers who are on the more serious end of this continuum, also known as 'career volunteers' (Stebbins, 1996, 2015). According to Elkington and Stebbins (2014, p. 23), conceptualising some serious leisure experiences as a 'career' effectively captures the complexity and 'sense of unfolding' of participants' roles within an organisation - and within their own lives - over time, including changing responsibilities and personal/work dynamics.

Understanding the experiences of career volunteers also involves a consideration of the balance between the rewards and costs associated with their serious leisure activity. Rewards relate to the motivations for and benefits of undertaking volunteer work (Elkington \& Stebbins, 2014). These can be classified as personal rewards, social 
rewards and thrills (Stebbins, 2014). Personal rewards relate to personal enrichment, self-actualization, self-expression, self-image, self-gratification, re-creation of self and financial return (Elkington \& Stebbins, 2014, p. 19). Social rewards, on the other hand, are characterised by social attraction, group accomplishment and contributing to the groups' development (Elkington \& Stebbins, 2014, p. 19). Thrills refer to 'sharply exciting events and occasions' (Stebbins, 2014, p. 12) or high points experienced during a serious leisure career.

However, volunteers must also often endure certain drawbacks or 'costs' to their serious leisure activity. Stebbins (2014, p. 11) asserts that, unlike rewards, 'it has been impossible to develop a general list' of costs since they are 'highly specific to each activity'. Costs are consequences of participation in serious leisure (which may or may not also act as constraints to participation) and can be broadly categorised as tensions, dislikes and disappointments (Stebbins, 1992, 2016). Tensions can arise from juggling work and family commitments and other leisure activities, which may result in 'temporal' (e.g. scheduling conflicts) or 'relational' (e.g. friction in spousal or parental relationships) tensions (Elkington \& Stebbins, 2014; Stebbins, 2004b). Tensions can also manifest as interpersonal problems between participants engaging in the same serious leisure activity, such as between volunteers in managerial roles and those they manage (Elkington \& Stebbins, 2014; Stebbins, 2004b, 2014). Dislikes can often stem from tensions, being substantial problems 'requiring the volunteer to adjust significantly, possibly even to leave the volunteer role', including dealing with power struggles, politics, administrative and management changes, and the 'behaviour of difficult persons and shortage of reliable volunteers' (Stebbins, 2004b, p. 209; Stebbins, 2005; Lamont et al., 2014). Finally, disappointments relate to perceived failures, 'poor 
results' or 'let-downs by others', and may be understood as the opposite of thrills (Stebbins, 2014; Lamont et al., 2014, p. 146).

Elkington and Stebbins (2014, p. 19) suggest that rewards usually outweigh the costs, so that the serious leisure activity still ultimately results in 'a high level of personal fulfilment'. Since volunteers are drawn to engage in their serious leisure because of the rewards it may yield, it is assumed that they will, therefore, persevere in spite of the costs involved, 'sticking with it through thick and thin' (Stebbins, 2016, p. 3; Stebbins, 2004a). Although rewards and costs should be understood in relation to one another, scholarly work has tended to focus more on rewards, leaving costs and perseverance under-theorised in the literature (Lamont et al., 2014, 2015; Stebbins, 2007). Empirical studies that do discuss the costs associated with serious leisure include explorations of, for example, participants in barbershop singing (Stebbins, 1992), dog sports (Baldwin \& Norris, 1999; Gillespie, Leffler, \& Lerner, 2002), amateur athletics competitions (Lamont et al., 2014; Major, 2001), volunteers at arts events (Bendle \& Patterson, 2008) and in community sport organisations (Misener, Doherty, \& HammKerwin, 2010).

In their review of empirical studies on the costs of serious leisure participation, Lamont et al. (2015, p. 649) identify seven key cost themes evident in the literature: (1) 'Significant consumption of personal resources (e.g., time, money)'; (2) 'Strained interpersonal relationships'; (3) 'Constrained leisure participation beyond core activity'; (4) 'Difficulty balancing everyday obligations (e.g., work, family, domestic duties) with serious leisure career’; (5) ‘Emotional costs'; (6) 'Physical injuries; and (7) 'Event cancellation'. Lamont et al. (2015) argue for 'substituting the concepts of costs and perseverance with the concepts of constraints and constraint negotiation' (p. 647), asserting that the latter is 'more theoretically advanced' and that using different 
terminology 'creates confusion and hinders the development of a coherent body of knowledge on serious leisure participation' (p. 651). However, Lamont et al.'s (2015) article does not consider the specificities of Stebbins' three categories of costs tensions, dislikes and disappointments - in depth. Indeed, the seven key cost themes guiding their discussion of costs appear to be focused primarily on what can be designated as tensions, with little attention given to dislikes and disappointments. Similarly, the visual summary of the serious leisure perspective produced by Veal (2017, p. 206) offers a list of costs - 'work clashes', 'family clashes', 'injuries', 'stage fright', 'frustrations' - without reference to tensions, dislikes and disappointments. In the present article, we aim to advance understandings of Stebbins' tensions-dislikesdisappointments framework through providing empirical evidence of how different costs manifest in the context of DIY heritage institutions of popular music's past.

\section{Career volunteering in heritage institutions}

Although no published work has yet explored the rewards and costs of volunteering in the community heritage sector from a serious leisure perspective, a small body of work exists that examines the benefits and motivations of heritage volunteers in mainstream heritage institutions (e.g. Deery, Jago, \& Mair, 2011; Edwards, 2005; Edwards \& Graham, 2006; Graham, 2004; Rhoden, Ineson, \& Ralston, 2009). Edwards (2005, p. 30), for example, lists eight core motivations for museum volunteers - 'personal needs, relationship network, self-expression, available time, social, purposive, free time, and personal interest' - while Rhoden et al. (2009, p. 19) notes six others - 'altruism, for me (work substitute), social/affiliative, instrumental (hobbies), for me (relaxation/change) and instrumental (skills)'. These motivations have clear parallels with Stebbins's conceptualisation of the 'rewards' associated with volunteering. 
Few studies, however, consider the potential drawbacks - the costs - of volunteering in heritage institutions. Even those studies that use a serious leisure framework focus on the extent to which heritage volunteers are motivated by selfinterest, accruing personal rewards and enhancing a sense a well-being (Cantillon \& Baker, 2018; Edwards, 2005; Orr, 2006; Stamer, Lerdall, \& Guo, 2008). Holmes (2009, p. 1) discusses some of the financial costs associated with volunteering - such as paying for travel, parking, uniforms and memberships - as well as time costs for those who also engage in paid work and volunteering at multiple organisations. In her article on volunteers in mainstream UK museums, Orr (2006) also mentions costs, but this is focused on the costs for the institution and its paid staff rather than for the volunteers themselves. Specifically, Orr (2006) argues that volunteers 'us[e] the museum space to make their own culture and contribute to the construction of their own identities' ( $p$. 203), and that these personal benefits for volunteers can 'negate the financial benefits to museums' (p. 206) in that paid staff are required to expend their time and energy to train and manage volunteers.

In regard to popular music heritage institutions specifically, some of this literature does consider the difficulties and anxieties volunteers may experience (see, e.g., Baker, 2017; Cantillon and Baker, 2019; Long, Baker, Istvandity, \& Collins, 2017). Cantillon and Baker (2019), for instance, observe that volunteers in DIY popular music heritage institutions experience a mix of 'pleasures' and 'pressures' associated with their work, with the latter relating predominantly to concerns over institutions' sustainability and resources. Baker (2017, p. 139-140) cautions against the idealisation and sentimentalisation of the DIY approach to heritage, observing that tensions and conflicts (e.g. complaints about people talking too much or being overbearing) were a 
part of the communities of practice created by volunteers in community museums and archives of popular music.

\section{Methodology}

This article draws on data from two Australian Research Council (ARC) funded projects which ran consecutively from 2010-2012 and 2013-2015. The first project explored how popular music's past appears in cultural memory and public culture. In addition to interviews with documentary makers, journalists and heritage practitioners in the mainstream heritage sector, the project also involved interviews with volunteers in six DIY heritage institutions. Emerging from and building upon that research, the second project investigated DIY heritage institutions as specialised repositories for popular music's material culture, and the contributions of volunteers in these places. Bringing together the DIY heritage institution interviews undertaken in the first project with those from the second project results in a combined data set consisting of semistructured ethnographic interviews (Spradley, 2016) conducted with 125 founders, volunteers and other heritage workers in 22 DIY archives, museums and halls of fame in ten countries (see Baker, 2017).

Fieldwork for the majority of research sites comprised single visits. In some cases opportunities to make multiple visits presented themselves, with the Australian Jazz Museum, for example, visited on six occasions between May 2011 and November 2015, including a two-week period of participant observation in October 2013. In some sites, only one or two people were interviewed, particularly in those places in which the founder of the institution was the sole volunteer, such as the Hector Country Music Heritage Museum and KD’s Elvis Presley Museum. When more than one person was involved in an organisation, interviews were arranged with multiple volunteers wherever possible. For example, 31 volunteers were interviewed at the Heart of Texas 
Country Music Museum and 26 volunteers participated at the Australian Jazz Museum. Interviewees were asked questions about the founding of the DIY heritage institution, the processes and practices of collection, preservation and display, and the pleasures and pressures of volunteering.

The interviews were audio recorded and transcribed verbatim with the resulting transcripts imported into NVivo. Coding occurred in two cycles. The first cycle involved a case study approach (Feagin, Orum, \& Sjoberg, 1991) in order for contextual information to be retained (Maxwell \& Chmiel, 2014). Interviews from the Australian Jazz Museum were coded according to the theoretical categories of the framework of rewards and costs put forward by Stebbins (2014) in his development of the serious leisure perspective. The second cycle adopted a comparative approach (Palmberger \& Gingrich, 2014), drawing on the full data set and narrowing the focus to codes and subcodes that had been established in cycle one relating to the costs of career volunteering.

The two research projects underpinning this article did not set out to apply the serious leisure perspective to DIY heritage practices undertaken by popular music enthusiasts. However, coding revealed the presence of costs in the interviewees' experiences of their career volunteering in 13 of the 22 DIY heritage institutions involved in the research (see Table 1). Discussions of costs tended to be in response to questions in the interview schedule around the challenges experienced by volunteers or problems faced by the organisation. To "explore the possible and plausible interaction of [the] major codes', the second cycle of coding was followed with a process of codeweaving which involves integrating the codes and subcodes 'into narrative form' (Saldaña, 2013, p. 248). Working through the coded data in this way revealed the material which was most suited to analysis using an SLP lens. 
Table 1. Research sites. Table adapted from Baker, 2017.

\begin{tabular}{|c|c|c|c|}
\hline Name of DIY institution & Mission & Location & Year founded \\
\hline $\begin{array}{l}\text { Australian Country Music } \\
\text { Hall of Fame }\end{array}$ & $\begin{array}{l}\text { Aims to collect, protect, } \\
\text { preserve and display the } \\
\text { history and heritage of } \\
\text { Australian Country } \\
\text { Music. }\end{array}$ & $\begin{array}{l}\text { Tamworth, } \\
\text { New South } \\
\text { Wales, } \\
\text { Australia }\end{array}$ & 1994 \\
\hline Australian Jazz Museum & $\begin{array}{l}\text { Established to collect, } \\
\text { exhibit, preserve and } \\
\text { store Australian jazz } \\
\text { music since } 1920 \text { s for } \\
\text { public use and research. }\end{array}$ & $\begin{array}{l}\text { Melbourne, } \\
\text { Victoria, } \\
\text { Australia }\end{array}$ & 1996 \\
\hline $\begin{array}{l}\text { Heart of Texas Country } \\
\text { Music Museum }\end{array}$ & $\begin{array}{l}\text { Aims to represent } \\
\text { country music's colorful } \\
\text { past through collection of } \\
\text { artist's memorabilia. }\end{array}$ & $\begin{array}{l}\text { Brady, Texas, } \\
\text { United States }\end{array}$ & 2000 \\
\hline $\begin{array}{l}\text { Hector Country Music } \\
\text { Heritage Museum }\end{array}$ & $\begin{array}{l}\text { Collects sheet music, } \\
\text { instruments, memorabilia } \\
\text { and other country music } \\
\text { related artifacts from } \\
\text { New Zealand and } \\
\text { international artists. }\end{array}$ & $\begin{array}{l}\text { Hector, South } \\
\text { Island, New } \\
\text { Zealand }\end{array}$ & 2002 \\
\hline $\begin{array}{l}\text { KD's Elvis Presley } \\
\text { Museum }\end{array}$ & $\begin{array}{l}\text { Aims to celebrate the life } \\
\text { of Elvis Presley through } \\
\text { display of ephemera. }\end{array}$ & $\begin{array}{l}\text { Hawera, North } \\
\text { Island, New } \\
\text { Zealand }\end{array}$ & c. 1986 \\
\hline Museum RockArt & $\begin{array}{l}\text { Exhibits artifacts relating } \\
\text { to Dutch rock and pop } \\
\text { music since the } 1950 \mathrm{~s} \text {. }\end{array}$ & $\begin{array}{l}\text { Hoek van } \\
\text { Holland, } \\
\text { Netherlands }\end{array}$ & 2004 \\
\hline Nederlands Jazz Archief & $\begin{array}{l}\text { Aims to preserve } \\
\text { documents pertaining to } \\
\text { jazz in The Netherlands. }\end{array}$ & $\begin{array}{l}\text { Amsterdam, } \\
\text { Netherlands }\end{array}$ & 1982 \\
\hline PopMuseum & $\begin{array}{l}\text { Aims to collect and } \\
\text { preserve documents and } \\
\text { objects of Czech and } \\
\text { Slovak pop music } \\
\text { history. }\end{array}$ & $\begin{array}{l}\text { Prague, Czech } \\
\text { Republic }\end{array}$ & 2000 \\
\hline Queensland Jazz Archive & $\begin{array}{l}\text { Aims to preserve the } \\
\text { heritage of Queensland } \\
\text { jazz. }\end{array}$ & $\begin{array}{l}\text { Brisbane, } \\
\text { Queensland, } \\
\text { Australia }\end{array}$ & c. 2000 \\
\hline
\end{tabular}




\begin{tabular}{|l|l|l|l|}
\hline $\begin{array}{l}\text { Rhode Island Music Hall } \\
\text { of Fame }\end{array}$ & $\begin{array}{l}\text { Dedicated to celebrating } \\
\text { past and present } \\
\text { musicians of Rhode } \\
\text { Island. }\end{array}$ & $\begin{array}{l}\text { Pawtucket, } \\
\text { Rhode Island, } \\
\text { United States }\end{array}$ & 2010 \\
\hline Sarasota Music Archive & $\begin{array}{l}\text { Aims to preserve various } \\
\text { genres of music heritage } \\
\text { for future generations. }\end{array}$ & $\begin{array}{l}\text { Sarasota, } \\
\text { Florida, United } \\
\text { States }\end{array}$ & 1980 \\
\hline $\begin{array}{l}\text { South Australian Jazz } \\
\text { Archive }\end{array}$ & $\begin{array}{l}\text { Exhibits and collects } \\
\text { audiovisual material of } \\
\text { jazz musicians in South } \\
\text { Australia. }\end{array}$ & $\begin{array}{l}\text { Adelaide, South } \\
\text { Australia, } \\
\text { Australia }\end{array}$ & 2003 \\
\hline SwissJazzOrama & $\begin{array}{l}\text { Documents the history of } \\
\text { jazz from around the } \\
\text { world. }\end{array}$ & $\begin{array}{l}\text { Uster, } \\
\text { Switzerland }\end{array}$ & 1989 \\
\hline
\end{tabular}

It is important to note before proceeding that in all interviews coded, explication of the rewards of volunteering far outweighed references to costs. Personal rewards related primarily to self-expression and self-actualisation. For example, volunteers reported the pleasure they experienced in having opportunities to apply their preexisting skills and knowledges, as well as the opportunities to develop new skills and knowledges, when undertaking their work in the DIY heritage institution (see Baker, 2017, pp. 118-125). Volunteering also yielded social rewards in the form of contributing to the common good, with enjoyment gained from helping others (see Baker, 2017, pp. 105-109), playing a part in the institution meeting its goals and objectives, and overall feeling part of something bigger. Thrills were also reported by the interviewees, such as when volunteers had meaningful interactions with visitors (see Baker, 2017, pp. 130-133), or when authorised accreditation bodies or mainstream heritage institutions recognised the importance and efficacy of the DIY heritage institution (see Baker, 2017, pp. 163-166). Although these rewards are what motivate career volunteers to take up and commit to their serious leisure activity, it is crucial to also understand the costs experienced along the way. 


\section{Results}

\section{Tensions}

While it is likely that interpersonal tensions are experienced to a certain degree and at some time by all volunteers, mention of interpersonal tensions were infrequent. An interview with two volunteers from the Sarasota Music Archive revealed they found engaging with other volunteers to occasionally be a frustrating experience. One reported 'some of the people I do not enjoy', providing the example of lunch breaks when she would be seated around a table with a group of people 'who don't talk', adding 'I can't stand it' (7 April 2014). In response, the other volunteer noted that there had been a change in lunchtime behaviour over time, and that when he started volunteering it had been a 'very congenial group ... and conversation would go on like crazy' (7 April 2014). These volunteers pointed to a clash in personalities as resulting in a shift in the quality of social interactions they were experiencing at the archive. In the Australian Jazz Museum, one volunteer reported having observed 'a little bit of resentment' towards volunteers whose activities were being 'financed' by government unemployment benefits - that is, while 'we're all doing the same work', some volunteers are effectively 'being paid' whereas others 'don't get money' (8 October 2013). The tension here was also related to the 'financed' volunteers arriving at the institution with no jazz knowledge. The volunteers with jazz knowledge questioned the capacity for volunteers without jazz knowledge to contribute meaningfully to the organisation. There were concerns around the additional labour involved in fixing cataloguing mistakes made by those without jazz knowledge, as well as anxiety around the institutional well-being of a jazz archive if the majority of volunteers have no jazz knowledge. 
Reference to relational and financial tensions were also scarce. A volunteer at the Australian Country Music Hall of Fame commented on how the partner of another volunteer 'puts up with' all the hours being worked, which affected the couple's vacation planning (4 August 2011). The volunteer in question, however, made no mention of relational tensions in their own interview, though did note they had not 'had holidays for years' (2 August 2011). Financial tensions, on the other hand, were highlighted by the founders of four DIY heritage institutions in regard to spending their own money to establish and maintain their museums, or forgoing paid work in order to devote their time to the institution. In all cases, however, the financial issues only received the briefest of mentions followed by reiteration of rewards. For example, the founder-curator of Museum RockArt observed, 'I used my own funds to build this place. Now I'm very poor, but very happy' (29 September 2011).

Temporal tensions related to work commitments, family commitments (namely, not having as much time as is needed by the institution or desired by the volunteer due to the need to care for young grandchildren) and, for one volunteer at SwissJazzOrama, the time for other leisure activities, including listening to records at home. The tensions around paid work were linked to both employment taking time away from volunteering, and volunteering taking time away from employment. For one volunteer, the time they needed to dedicate to their career volunteering in order to establish strong foundations for the DIY heritage institution they had been involved in founding was interfering with 'earning a living' (14 April 2014). They were volunteering substantial amounts of time to the organisation, while also needing to undertake work that would provide an income. Not having enough time to do both was creating significant strain, with the volunteer acknowledging 'I don't know how long I can keep up this pace' (14 April 2014). The other references to work commitments in interviews were focused on paid work getting 
in the way of spending the time needed at the DIY heritage institution. One volunteer from Queensland Jazz Archive noted that 'one of the big problems' is having 'too many other things going on', with work 'tak[ing] up, by far, the majority of my time', resulting in 'very little' time being available for archival tasks (20 March 2014). For the founder of KD's Elvis Presley Museum, the demands of paid employment were 'the big challenge' for running a small museum particularly in relation to work hours: 'I found the thing is just to try and keep the public happy, because I was getting phone calls and I am not here. And I said, "Look, can you be here at 4 or 5[pm after I finish work]?"' (10 February 2014). The sense of disappointing others due to the demands of paid work was also articulated by a volunteer at Heart of Texas Country Music Museum who had 'taken on another part time job and that got in the way of helping ... [and] I said [to the founder], "I know I let you down this year"” (4 April 2014). In response, another volunteer added 'That's the only thing about working, it gets in the way' (4 April 2014).

Volunteer well-being emerged as a significant tension. Volunteers experienced a range of difficult feelings in the course of their work, leading to concerns around emotional well-being. For example, the founder-curator of the Hector Country Music Heritage Museum described how he 'get[s] a wee bit depressed when no one comes' to the museum (14 February 2014), while a volunteer at the Australian Country Music Hall of Fame said that archival tasks involving digitisation were 'frightening' due to a lack of 'expert' knowledge with how to use the technology properly - 'it scares the hell out of me', she said of the machine being used to digitise the archive's photographs (2 August 2011). A volunteer at PopMuseum highlighted the difficulties in navigating the emotions of people whose family member has just died when the archive needs to negotiate procurement of the deceased's collection before it gets thrown out (8 July 2014). 
Tensions were also linked to physical well-being. One volunteer at the Australian Jazz Museum described the physical effects of spending the day cataloguing at the computer:

accuracy's quite important to this - it is the most important aspect of my job. And if I feel I can't get it right because you know, I'm sort of getting cross-eyed and I get a headache, that's when I say no, that's it, I've got to go [home]. (1 October 2013)

A volunteer at the Sarasota Music Archive made a similar observation, stating that on some days there are very few volunteers at the computer terminals - 'If you're not well and we're ageing, sometimes you just can't [be here]' (8 April 2014). Physical wellbeing was most at-risk when there was a shortage of volunteers for projects. As one volunteer from Heart of Texas Country Music Museum observed, 'I used to say they're [the volunteers] tireless, but they're not, [the founder] wore them out this year' (4 April 2014). Ageing bodies limit what is possible, and sometimes the desire to continue volunteering is not matched by the ability to do so.

\section{Dislikes}

One of the most prominent dislikes mentioned by participants related to the challenges of relying on a volunteer workforce. Perhaps indicative of the difficulties interviewees had in talking about dislikes, a volunteer at Heart of Texas Country Music Museum apologetically began 'I don't mean to be ugly', before saying 'you do find volunteers that they say they will be there to help, but they're not dependable' (4 April 2014). At the Sarasota Music Archive, concerns about dependability were highlighted in relation to finding people to staff the front desk on a long-term basis. One volunteer indicated that volunteers are reluctant to take on that role because they 'don't want that kind of responsibility' (7 April 2014). The role involves 'having to greet the public and relate 
[to them]', as well as retail tasks involved in the sale of second hand vinyl. This volunteer indicated that they were tasks not viewed as favourable and 'a lot of people just want to sit in the back', prompting another volunteer to add 'we have some people who just sit there, refuse to do anything' (7 April 2014). Dislikes relating to the volunteer workforce are also connected to interpersonal tensions - volunteers become frustrated with individuals who don't pull their weight.

A shortage of volunteers, or the presence of volunteers who are not seen to pull their weight in the organisation, creates feelings of fatigue for more industrious volunteers and especially those in management roles. At the Australian Country Music Hall of Fame, a lack of volunteers was viewed as the major concern of the archive. As one volunteer indicated, 'we can probably live without [more] space [for the growing collection] by being creative, but without the people, it's running a lot of the main - the key people - into the ground' (2 August 2011). The 'key people' being referred to here end up putting more time into volunteering than they would if there were more volunteers to share the load, with another interviewee saying, 'five days a week can tire you out ... we can't continue to do five days [a week]' (9 June 2011). Similarly, at the South Australian Jazz Archive, a volunteer spoke of a period where, due to a range of unforeseeable circumstances, they were left to run the archive alone for a week: 'I do think this week's exercise with me the only person on the executive handling the whole thing is too much. I didn't sleep very well last night' (11 June 2013). In these examples, which also relate to tensions concerning physical and emotional well-being, fatigue is linked to the effects of ageing - both respondents were aged in their 70s and $80 \mathrm{~s}-$ coupled with a shortage of volunteers. Importantly, this issue extends beyond their personal experiences of fatigue (a well-being tension) to bigger issues related to institutional sustainability (see also Baker \& Cantillon, 2019) - that is, how long can 
they feasibly sustain their own volunteering activities, and who will take over when they are gone?

Frustration and fatigue were also linked to ramifications arising from a lack of care being exercised by volunteers undertaking archival tasks. As already noted above, accuracy in data entry was viewed as essential to the work of the DIY heritage institution. At the Sarasota Music Archive, a volunteer emphasised the importance of comma placement when entering items into the archive's catalogue, with the comma determining if the item will be found in later searches: 'sometimes people are not as careful as they should be, so they don't always put in that comma' (7 April 2014). They suggested that the lack of care is because 'we are volunteers, we don't get paid' ( 7 April 2014). At the Australian Country Music Hall of Fame, cataloguing errors were attributed to volunteers being 'non-librarian', that is without formal training in archiving and librarianship, and so without the necessary skills and expertise to work with databases. One volunteer noted that despite the hall of fame having a cataloguing system that was 'designed so that it holds your hand', 'even the good people' make errors in their data entry (2 August 2011).

In DIY heritage institutions that had achieved, or were working toward, museum standards accreditation, cataloguing errors were considered grievous. The collections manager at the Australian Jazz Museum explained that volunteers were on a spectrum of ability, from those 'who can do very detailed and very accurate database work' to those who are 'not capable or they don't want to' do tasks accurately (26 June 2012). The latter group of volunteers are a burden to the collections team, and potentially to the archive more generally. It is not a simple case of redirecting people's energies away from cataloguing and into another part of the archive, for as the collections manager pointed out, 'what you often find is that if they're inaccurate in [cataloguing], they're 
[inaccurate] in other things as well' (26 June 2012). Managing the abilities of volunteers with the needs of the archive is 'always a balancing act' (8 October 2013), draining the energies of an over-stretched management team and the good-will of more skilled volunteers. A volunteer at the Queensland Jazz Archive noted that when the accuracy of other volunteers' work is doubted, the more able volunteer takes on the burden of the task themselves as a way to save 'a hell of a lot of time' and ensure 'an accurate transfer of information' - 'it's easier to do it myself' (20 March 2014).

Another dislike communicated by volunteers related to ineffective leadership. In a discussion of the organisation that led to the emergence of what is now the Australian Country Music Hall of Fame, a volunteer described 'very serious problems' with the organisation's leadership which meant it 'nearly went out of business':

after about 18 months of what I called - how can I put this politely - there was a lot of show pony stuff, you know, with meetings and tea and bikkies for important people, etc, etc, but nothing was actually being done ... in actually collecting material, and with a view to preserving it. (9 June 2011)

As another volunteer from the hall of fame explained, in those early years of the organisation there was 'no real direction' (2 August 2011). There was also a suggestion that some members of the current board are 'not able to devote the time that's necessary' to the running of the organisation beyond 'toddl[ing] up for a board meeting' (2 August 2011). Concerns about leadership were primarily in regard to committee members on the boards of DIY heritage institutions not pulling their weight or their lack of vision for the organisation and what this might mean for the institutions' mid- to long-term sustainability. In the words of one volunteer, 'unless the Queensland Jazz Archive goes down the track that the Victorian Jazz Archive [former name of the AJM] [went] down, for instance, then... I don't know. The committee just don't seem to have that wider vision of what and how to keep the stuff and how to disseminate it' (20 
March 2014).

\section{Disappointments}

Being let down by others was the most prevalent disappointment communicated in the interviews. This was primarily in reference to potential collaborators external to the DIY heritage institution whose assistance had failed to materialise. One volunteer described how Sarasota Music Archive had found 'a major figure' in the community who expressed interest in implementing a 'work-study program' at the archive that could increase the number of young, 'computer savvy' volunteers (8 April 2014). Two years had passed and no progress had been made. The experience was described by the volunteer as 'frustrating' - 'I thought that would be a perfect fit ... you see all these things that need to be done, and you can't quite get it done because it takes two to tango' (8 April 2014). Similar frustrations were experienced by volunteers at the South Australian Jazz Archive. The volunteers had developed a promising connection with a local university's jazz department which they hoped would lead to students accessing the material or volunteering. However, at the time of the interviews this had not eventuated. In both cases, the disappointment is in the lost opportunity to secure younger volunteers, which would help address urgent sustainability concerns held by these organisations.

In a different case of feeling let down by external parties, a volunteer at the Australian Country Music Hall of Fame explained at length how another organisation in the local community had attempted to trademark their name. The DIY heritage institution had not registered their name as a trademark when they first opened, and when they later initiated the registration process, the volunteers discovered that 'somebody else in town was trying to take our name' (3 August 2011). This caused 'a bit of a kerfuffle' and resulted in the volunteers needing to navigate the complexities of 
trademark registration: 'a lot of the legislation is so wide open, you know, you could drive a truck through it' (3 August 2011). When one volunteer 'hit a brick wall', another volunteer took over:

we got in touch with the trademark people, and they said, 'well, you can appeal', so we appealed, and we had a couple of meetings with the hierarchy of the [local organisation that had registered the trademark], and they were not too pleasant, but eventually they withdrew their application, and we had enough information on our application for it to go through. (3 August 2011)

Disappointments also manifested in response to poor results. At the Australian Jazz Museum, the most significant disappointments arose from unsuccessful grant applications. One volunteer noted that the institution has "no regular funding, and we scrabble for every cent that we can get' (19 July 2011). The museum depends on grants (among other income sources) for its continued survival, but funding schemes are becoming more and more competitive: 'the grants have dried up somewhat for a number of reasons, principally because the amount of money shrunk but the number of organisations seeking this is increasing' (30 November 2015). Volunteers explained that funding applications are often complicated and time-consuming, meaning that considerable work goes into applications that have low success rates: 'you think to yourself, “well, why bother?", because there's so much effort goes into them ... And then you miss out' (26 June 2012).

At the Nederlands Jazz Archief, organisational change was the biggest disappointment expressed by volunteers. As outlined by Baker (2017, p. 36), the 'closure of Muziek Centrum Nederland in 2012 due to the withdrawal of state funding saw the collection of the Nederlands Jazz Archief ... moved to the Special Collections archive of the University of Amsterdam'. At the time of the interviews in 2013, the archive's founders were still in the process of setting new parameters for the archive's 
heritage initiatives, with volunteer activities having ceased in mid-2012. The founders recognised that the organisational change had left the volunteers 'feeling kind of redundant' (4 February 2013). While the volunteers acknowledged there are opportunities elsewhere in the community for volunteering ('I have several other jobs. So that's not a problem'), the work they were undertaking at the Nederlands Jazz Archief was seen as having particular kinds of rewards not readily available elsewhere. One volunteer explained the organisational change had left them feeling 'uncomfortable'. They worried that the materials they had been working with materials he described as 'my collection' - were at risk:

I miss the project. I hope I can finish the project and complete it and I'm not sure about that because of the relocations and it's fragile. The project is fragile and it's vulnerable to spread out and I hope I find it back. (5 February 2013)

In this case, issues with organisational change also foster tensions around emotional well-being, with volunteers worried about the state of the collection and missing their access to it.

\section{Discussion}

Despite the concerns put forth by Lamont and colleagues (2015) about costs being an underdeveloped and ambiguous concept in the serious leisure perspective, we found that Stebbins' tripartite model of tensions, dislikes and disappointments provides a useful framework for a discussion of the personal and organisational costs experienced by career volunteers in DIY heritage institutions. Table 2 provides a summary of the types of costs identified in our dataset, drawing on the three broad categories outlined by Stebbins, some of the costs identified by Lamont et al. (2015), and other cost types that emerged from our data. Specifically, we found that tensions could be distinguished as 
interpersonal, relational, financial, temporal (work, family, leisure), and well-being (emotional, physical). Dislikes centred primarily on shortages of dependable volunteers, volunteers who demonstrate a 'lack of care', and ineffective leadership.

Disappointments focused on being let down by others, unsuccessful funding applications, and organisational change. It is important to note that there is considerable overlap of and interconnectedness between these cost types. For example, dislikes such as a lack of accuracy in volunteers' work or ineffective leadership can easily lead to interpersonal tensions, and disappointments can impact negatively on physical and emotional well-being when volunteers feel frustrated and fatigued.

Table 2. Summary of costs identified in DIY heritage institutions focused on the preservation of popular music's past.

\begin{tabular}{|c|c|}
\hline Cost category & Type of cost \\
\hline \multirow[t]{5}{*}{ Tensions } & Interpersonal \\
\hline & Relational \\
\hline & Financial \\
\hline & $\begin{array}{cl}\text { Temporal } \\
\text { - } & \text { Work } \\
- & \text { Family } \\
- & \text { Leisure }\end{array}$ \\
\hline & $\begin{array}{l}\text { Well-being } \\
-\quad \text { Emotional } \\
\text { - } \quad \text { Physical }\end{array}$ \\
\hline \multirow[t]{3}{*}{ Dislikes } & Shortage of dependable volunteers \\
\hline & Volunteers who demonstrate a 'lack of care' \\
\hline & Ineffective leadership \\
\hline
\end{tabular}




\begin{tabular}{|l|l|}
\hline Disappointments & Being let down by others \\
\cline { 2 - 2 } & Unsuccessful funding applications \\
\cline { 2 - 2 } & Organisational change \\
\hline
\end{tabular}

None of the tensions, dislikes or disappointments were accompanied by a notion that the volunteer would not persevere if possible. Even in the case of the Nederlands Jazz Archief, volunteers still expressed interest and commitment to the project even though they were not able to actively fulfill their duties due to organisational change. For volunteers in DIY heritage institutions, rewards far outweighed the costs of their participation, and perseverance was therefore core to their ongoing pursuit of rewards and their accrual of skills and knowledge. A volunteer at the Australian Country Music Hall of Fame described the volunteers there as having 'sticktoitivity', saying 'people here feel it is important to keep going ... we believe in that' (2 August 2011). Lamont et al. (2014, p. 146) observe studies have shown that the value of rewards can render costs 'insignificant' (see also Baldwin \& Norris, 1999). We suggest that costs are not insignificant - they were significant enough to be raised in the interviews - but rather they are not significant enough to cause volunteers to cease their activities. Costs did not restrict participation - an inability to persevere was usually due to factors unrelated to volunteering, such as reduced physical well-being (death, ill health). Interestingly, the therapeutic rewards gained from career volunteering work to support a sense of physical and emotional well-being, and this can be a key motivator for perseverance when costs are encountered (see Cantillon \& Baker, 2018).

Serious leisure is 'textured and complex' (Gallant, Arai, \& Smale, 2013, p. 94), and costs are experienced alongside and in relation to rewards, not in isolation. Indeed, perseverance through costs can serve to amplify the satisfaction of rewards. As 
Elkington and Stebbins (2014, p. 18) suggest, 'deepest fulfilment sometimes comes from the end of the activity rather than during it, from sticking with it through thick and thin, from conquering adversity'. For instance, grant application rejections are disappointing, but through perseverance a DIY institution may eventually succeed, resulting in a collective thrill for volunteers. Similarly, in the case of the Australian Country Music Hall of Fame discussed above, there was disappointment experienced when another local organisation tried to trademark their name. However, the volunteers persisted with an appeal, and were eventually successful. One volunteer who lead the appeal process said: 'that was probably one of the feathers in my cap of working here, was doing that, and feeling that you'd accomplished something' (3 August 2011). In DIY heritage institutions, perseverance is not only an individual orientation, but a shared practice that is bolstered by the affective and social dimensions of these places (Cantillon \& Baker, 2018). Therefore, costs, rewards and perseverance are often experienced at both individual and collective levels as groups of volunteers strive to support institutional well-being (see Baker \& Cantillon, 2019) and efficacy amid their own personal circumstances and motivations.

\section{Conclusion}

Career volunteering in DIY popular music heritage institutions is characterised by complex dynamics of costs, rewards and perseverance. Although Lamont et al. (2014, 2015) raise concerns about the usefulness of Stebbins' conceptualisations of costs and perseverance, we found that his tripartite model of tensions, dislikes and disappointments proved valuable for examining the experiences of volunteers in DIY heritage institutions focused on the collection, preservation and curation of popular music's material culture. The costs associated with participation in DIY heritage institutions are diverse and have individual and organisational consequences, suggesting 
that costs should not be 'treated as a peripheral issue' in studies of serious leisure careers (Lamont et al., 2015, p. 649).

Although this article has focused on DIY heritage institutions of popular music specifically, the findings are likely relevant to the community heritage sector more broadly. Indeed, the costs discussed in this article are shaped less by the specific subject focus of the DIY heritage institutions (in this case, popular music), and more by the conditions, functions and challenges that are characteristic of heritage initiatives in the community heritage sector (see Baker \& Cantillon, 2019). Understanding the costs experienced by individual volunteers and those collectively experienced by the volunteering body, as well as conditions for perseverance, may assist the managers of community heritage institutions in addressing issues related to institutional well-being, with the mid- to long-term sustainability of these places often connected to the retention and recruitment of volunteers (see also Baker, 2017; Baker \& Cantillon, 2019). The data also emphasised the extent to which different costs overlap and feed into one another, which highlights the need to mitigate certain costs to ensure rewards are maximised for volunteers and that the efficacy of the organisation is maintained.

\section{References}

Baker, S. (2017). Community custodians of popular music's past: A DIY approach to heritage. London: Routledge.

Baker, S., \& Cantillon, Z. (2019). Safeguarding Australia's community heritage sector: A consideration of the institutional wellbeing of volunteer-managed galleries, libraries, archives, museums and historical societies. Australian Historical Studies. doi.org/10.1080/1031461X.2019.1659836.

Baldwin, C., \& Norris, P. (1999). Exploring the dimensions of serious leisure: 'Love me - love my dog!' Journal of Leisure Research, 31(1), 1-17. 
Bendle, L., \& Patterson, I. (2008). Serious leisure, career volunteers and the organisation of arts events in a regional Australian city. International Journal of Event Management Research, 4(1), 1-11.

Cantillon, Z., \& Baker, S. (2018). DIY heritage institutions as third places: Caring, community and wellbeing among volunteers at the Australian Jazz Museum. Leisure Sciences. Advance online publication. doi:10.1080/01490400.2018.1518173.

Cantillon, Z., \& Baker, S. (2019). Affective qualities of creative labour. In M. Deuze \& M. Prenger (Eds.), Making media: Production, practices, and professions (p. 287-296). Amsterdam: Amsterdam University Press.

Deery, M., Jago, L., \& Mair, J. (2011). Volunteering for museums: The variation in motives across volunteer age groups. Curator: The Museum Journal, 54(3), $313-325$.

Dekker, P., \& Halman, L. (2003). Volunteering and values: An introduction. In P. Dekker \& L. Halman (Eds.), The values of volunteering: Cross-cultural perspectives (pp. 1-17). New York, NY: Kluwer Academic/Plenum Publishers.

Edwards, D. (2005). It's mostly about me: Reasons why volunteers contribute their time to museums and art museums. Tourism Review International, 9, 21-31.

Edwards, D., \& Graham, M. (2006). Museum volunteers: A discussion of challenges facing managers in the cultural and heritage sectors. Australian Journal on Volunteering, 11(1), 19-27.

Elkington, S., \& Stebbins, R. A. (2014). The serious leisure perspective: An introduction. London: Routledge.

Feagin, J. R., Orum, A. M., \& Sjoberg, G. (Eds.) (1991). A case for the case study. Chapel Hill, NC: University of North Carolina Press. 
Gallant, K., Arai, S., \& Smale, B. (2013). Celebrating, challenging and re-envisioning serious leisure. Leisure/Loisir, 37(2), 91-109.

Gillespie, D., Leffler, A., \& Lerner, E. (2002). If it weren't for my hobby, I'd have a life: Dog sports, serious leisure, and boundary negotiations. Leisure Studies, 21(3-4), 285-304.

Graham, M. (2004). Volunteering as heritage/volunteering in heritage. In R. A. Stebbins \& M. Graham (Eds.), Volunteering as leisure/leisure as volunteering: An international assessment (pp. 13-30). Wallingford: CABI Publishing.

Holmes, K. (2009). The value of volunteering: The volunteers' story. Australian Journal on Volunteering, 14, 1-9

Lamont, M., Kennelly, M., \& Moyle, B. (2014). Costs and perseverance in serious leisure careers. Leisure Sciences, 36(2), 144-160.

Lamont, M., Kennelly, M., \& Moyle, B. D. (2015). Toward conceptual advancement of costs and perseverance within the serious leisure perspective. Journal of Leisure Research, 47(5), 647-654.

Leonard, M. (2018). Representing popular music histories and heritage in museums. In S. Baker, C. Strong, L. Istvandity, \& Z. Cantillon (Eds.), The Routledge Companion to popular music history and heritage (pp. 261-270). London: Routledge.

Long, P., Baker, S., Istvandity, L., \& Collins, J. (2017). A labour of love: the affective archives of popular music culture. Archives and Records, 38(1), 61-79.

Major, W. (2001). The benefits and costs of serious running. World Leisure Journal, 43(2), 12-25. 
Maxwell, J. A., \& Chmiel, M. (2014). Notes toward a theory of qualitative data analysis. In U. Flick (Ed.), The SAGE handbook of qualitative data analysis (pp. 21-34). London: SAGE.

Misener, K., Doherty, A., \& Hamm-Kerwin, S. (2010). Learning from the experiences of older adult volunteers in sport: A serious leisure perspective. Journal of Leisure Research, 42(2), 267-289.

Orr, N. (2006). Museum volunteering: Heritage as 'serious leisure'. International Journal of Heritage Studies, 12(2), 194-210.

Palmberger, M., \& Gingrich, A. (2014). Qualitative comparative practices: Dimensions, cases and strategies. In U. Flick (Ed.), The SAGE handbook of qualitative data analysis (pp. 94-108). London: SAGE.

Rhoden, S., Ineson, E. M., \& Ralston, R. (2009). Volunteer motivation in heritage railways: A study of the West Somerset Railway Volunteers. Journal of Heritage Tourism, 4(1), 19-36.

Roberts, L., \& Cohen, S. (2014). Unauthorising popular music heritage: Outline of a critical framework. International Journal of Heritage Studies, 20(3), 241-261.

Saldaña, J. (2013). The coding manual for qualitative researchers (2nd ed.). London: SAGE.

Spradley, J. P. (2016). The ethnographic interview. Long Grove, IL: Waveland Press.

Stebbins, R. (1992). Costs and rewards in barbershop singing. Leisure Studies, 11(2), $123-133$.

Stebbins, R. A. (1996). Volunteering: A serious leisure perspective. Nonprofit and Voluntary Sector Quarterly, 25(2), 211-224. 
Stebbins, R. A. (2004a). Introduction. In R. A. Stebbins \& M. Graham (Eds.), Volunteering as leisure/leisure as volunteering: An international assessment (pp. 1-12). Wallingford: CABI Publishing.

Stebbins, R. A. (2004b). Serious leisure, volunteerism and quality of life. In J. T. Haworth \& A. J. Veal (Eds.), Work and leisure (pp. 200-212). London: Routledge.

Stebbins, R. A. (2005). Inclination to participate in organized serious leisure: An exploration of the role of costs, rewards, and lifestyle. Leisure/Loisir, 29(2), $183-201$.

Stebbins, R. A. (2007). Serious leisure: A perspective for our time. New Brunswick, NJ: Transaction.

Stebbins, R. A. (2014). Careers in serious leisure: From dabbler to devotee in search of fulfillment. London: Palgrave Macmillan.

Stebbins, R. A. (2015). Leisure and the motive to volunteer: Theories of serious, casual and project-based leisure. London: Palgrave Macmillan.

Stebbins, R. A. (2016). Costs, constraints, and perseverance. Journal of Leisure Research, 48(1), 1-4.

Stamer, D., Lerdall, K., \& Guo, C. (2008). Managing heritage volunteers: An exploratory study of volunteer programmes in art museums worldwide. Journal of Heritage Tourism, 3(3), 203-214.

Veal, A. J. (2017). The serious leisure perspective and the experience of leisure. Leisure Sciences, 39(3), 205-223. 